IJMS 2016 vol. 4 (1): 48-57

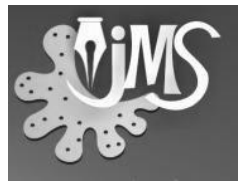

International Journal of Multidisciplinary

Studies (IJMS)

Volume 4, Issue 1, 2017

DOI: http://doi.org/10.4038/10.4038/ijms.v4i1.36

\title{
Decolorization of CI Direct Blue 201 Textile Dye by Native Bacteria
}

Ekanayake EMMS and Pathmalal M Manage

Centre for Water Quality and Algae Research, Department of Zoology, University of Sri Jayewardenepura, Sri Lanka

\begin{abstract}
Water pollution from untreated or partially treated textile dye effluents is one of the major problem concerns globally. Synthetic dyes extensively are used for textile dyeing process. They are highly recalcitrant to natural decolorization and degradation processes and will create drastic negative impacts on natural environment. Remediation of synthetic textile dyes through biological agents has been recorded as low cost and environmental friendly alternative for expensive chemical and physical treatment methods. Therefore the present study was aimed on the determination of CI Direct Blue 201 textile dye decolorizing ability by isolated bacteria strains. Among the 35 bacteria strains isolated from effluents of textile industries, five bacteria strains have shown remarkable decolorizing abilities on CI Direct Blue textile dye. The isolated bacteria were tentatively identified as Pseudomonas sp.1, Pseudomonas sp.2, Bacillus sp.1, Bacillus sp.2 and Micrococcus sp. by morphological features and biochemical tests. Decolorization kinetics of bacteria was recorded after 14 days of incubation with CI Direct Blue 201 dye treated at 75 ppm. Descending order of dye decolorization was resulted by Pseudomonas sp.2 (58.15 \pm 0.92\%), Bacillus sp.2 (55.02 $\pm 0.70 \%)$, Pseudomonas sp.1 (54.73 \pm 1.99\%), Micrococcus sp. (51.86 \pm 0.49\%) and Bacillus sp. 1 (51.55 $\pm 0.74 \%)$ at 280C respectively. Descending decolorization potential was shown by all bacteria as a response for the ascending initial concentration of dye. The highest decolorization of dye was recorded by Pseudomonas sp.2 as $67.93 \pm 1.23 \%$ at 50 ppm. High decolorization percentages were obtained when bacteria were incubated at 320C compared to 280C and 240C. Results of the present study revealed that isolated bacteria will be successful aspirants for remediation of synthetic textile dyes as an ecofriendly bioremediators to consider for green application approaches. However further studies are needed to understand their dye degradation mechanism in natural environment.
\end{abstract}

KEYWORDS: Bioremediation; dye decolorizing bacteria; CI Direct blue 201; Azo dye

Corresponding author: Pathmalal M Manage, email: pathmalal@sjp.ac.lk 


\section{INTRODUCTION}

Dyes are the substance which adhere to compatible surfaces and then provide permanent or temporal color, when applied to a substrate (Chequer et al., 2011). The adherence of dye to compatible surfaces can be by forming complexes or covalent bonds with metals or salts, by mechanical retention or by physical adsorption (Pereira \& Alves, 2012). Expansions in the chemical based industries are one of the major sources which resulted in an ever increasing reliance on anthropogenic organic chemicals (Andreoni \& Gianfreda., 2007). Most of industries including textile, cosmetics, paper, pharmaceutical, food and beverages use wide variety of dyes in different aspects. Among these various types of industries, textile dye industry accounts for two third of the total dye stuff production (Abraham et al., 2003; Azhar et al., 2005). In global scale, over 0.7 million tons of syntheic dyes are manufactured annually in the aspect of 100,000 different dyes (Chen et al., 2003).

Azo, anthraquinone and phthalocyanine dyes are the three most widely used goups of dyes in all around the world (Banat et al., 1996). Out of these three types of dyes, azo dyes are the largely employed group of synthetic dye in textile industry (O'Neill et al., 1999), which accounts for more than $50 \%$ of annual dye production (Puvaneswari et al., 2006; Saratale et al., 2009). With massive development of textile industry, discharge of dye containing untreated effluent water into public drains in the form of wastewater was recorded both locally and internationally and it was highlighted that such wastewater eventually pour out into rivers or tributaries nearby (Crini, 2006; Mahagamage \& Manage, 2014). As textile manufacturing is one of the largest industrial producers of wastewater, its' untreated or partially treated effluents are finally end up in natural waters has become one of the biggest problems in modern society (Chequer et al., 2011; Claudio et al., 2007).

Synthetic textile dyes are normally designed to be resistant to chemical, microbial, thermal and photolytic degradation (Chequer et al., 2011). Therefore, most colored and toxic textile dyes are highly persist and long lasting in the natural environment and primarily affect the quality of surface water which consequently contaminate the ground water aquifers (Engade \& Guptha, 2007). Release of dyes into environment, badly affect on aquatic flora and fauna, aquatic microorganisms, soil fertility and ecosystem integrity as well (Mahagamage \& Manage, 2014; Zhou \& Xiang, 2013). The effluents from the textile industry are one of those wastewaters that are hard to treat acceptable level because they are highly variable in composition (Willmott et al., 1998 as cited in Robinson et al., 2001). Various combinations of physical and chemical methods are being used to remove coloring substances in dye-containing effluents (Chang et al., 2002). However most of the methods are not viable options for treating large scale waste streams due to some drawbacks such as, less effective for highly colored and toxic dyes, economically unfeasible due to high initial and operating cost, generating significant amount of sludge (Chang et al., 2002; Kalyani et al., 2008). Hence, it is essential to find for an alternative technology for treating textile effluents. Biological treatments, which are based on the use of native organisms for decolorization and detoxification of textile wastewater have achieved growing concern as it has greater efficiency than the conventional methods (Asad et al, 2007; Saratale et al., 2009). Thus present study was employed native bacteria which were isolated from waste water effluent of textile dyes to study possible use of them as alternative ecofriendly method to remove CI Direct Blue 201 textile dye.

\section{MATERIALS AND METHOD}

\section{Sampling}

Water samples were collected into sterilized glass bottles from two sampling locations, BOI Avissawella (6097'10.93”N, 80020'49.96”E) and Pugoda (6097'94.45'N, 80011'91.08”E), 
which regularly face for textile effluents. Sampling was carried out in triplicates. Temperature, pH (Model: pH3110, WT Co., Weilheim, Germany), Dissolved Oxygen (DO) (Model: DO3110, WT Co., Weilheim, Germany) and conductivity (Model: Cond3110, WT Co., Weilheim, Germany) were measured at the site itself by using standard digital meters. Collected water samples were placed in ice box and transported to the laboratory within 4 hours of sampling and were stored at 40C until analyze. Chemical analysis for nitrate nitrogen and phosphate were carried out within 48 hours of sampling by standard spectrophotometric methods (APHA, 1995).

\section{Synthetic dye and chemicals}

CI Direct Blue 201 dye was obtained from local textile dyeing industry and used as a model dye during the study period. The $\mathrm{pH}$ of the dye was determined by dissolving $0.01 \mathrm{~g}$ of dye in $100 \mathrm{ml}$ deionized water and $\mathrm{pH}$ was found to be 8.1. All other chemicals used for the study was the highest purity available and analytical grade.

\section{Estimation method for CI Direct Blue 201 textile dye}

Absorption spectrum of CI Direct Blue 201 dye was obtained on a spectrophotometer and the maximum absorbance was found to be at 570nm. Calibration curve for CI Direct Blue 201 dye was plotted by considering the concentrations of the dye on $\mathrm{X}$ axis and their absorbance values recorded at $570 \mathrm{~nm}$ on $\mathrm{Y}$ axis. According to the Beer Lambert law, the slope and intercept of the curve provide a relationship between absorbance and concentration, where absorbance is less than 1.000 (Harvey, 2000). The graph was referred to determine the concentration of residual dye. Color removal percentage was determined by equation given below (Gupta et al., 2011), where $\mathrm{C} 1$; initial concentration while C2 is the final concentration.

Decolorization percentage $(\%)=[(\mathrm{C} 1-$
$\mathrm{C} 2) / \mathrm{C} 1] 100$

\section{Isolation of dye decolorizing bacteria}

Enrichment study for screen textile dye decolorizing bacteria was carried out in triplicates for each water samples. Water samples were subjected to spike dye at final concentration of 50ppm and kept in incubator (Model: KS 4000i, UK) at $25 \pm 10 \mathrm{C}$ for a period of 14 days (Manage et al., 2009a) under static conditions (Saratale et al.,2009; Jadhav et al., 2012). After 14 days of enrichment, $1 \mathrm{ml}$ of sub sample was removed from each flask and serial dilution was made up to 10-5 by using sterilized saline water. Standard pour plate method and streak plate method were followed and incubated in dark at 250C for 5 days to isolate pure bacterial colonies (Manage et al., 2009b). The isolated bacteria strains were maintained on LB agar slants at 40C and sub cultured twice a week (Manage et al., 2010).

\section{Dye decolorization}

Isolated bacteria were starved prior to the decolorization experiment. For starvation procedure, a loop full of isolated bacterial strains were inoculated into $5 \mathrm{ml}$ of liquid LB medium individually and incubated $24 \mathrm{~h}$ at $250 \mathrm{C} \pm 10 \mathrm{C}$ under static conditions to obtained exponentially growth cultures. After 24h, pellets of exponentially growing bacteria cultures were subjected to centrifugation (Model: Minor 35, UK) for 15 minutes at $8000 \mathrm{rpm}$ and washed twice in sterile saline water $(0.01 \mathrm{M}$ sodium chloride) following centrifugation. Resulted bacteria suspensions were removed and incubated overnight at $250 \mathrm{C} \pm 10 \mathrm{C}$ under static conditions to deplete the residual carbon if any. Turbidity of the bacteria cell suspensions were equalized (A590 $=$ 0.35) using spectrophotometer (Manage et al., 2009 a, 2009b \& 2010).

To determine the dye degrading ability of isolated bacteria strains, $1 \mathrm{ml}$ of each bacteria suspension (equalized to $\mathrm{A} 590=0.35$ ) was inoculated into separate sterilized universal bottles which contained filter sterilized dye, 
(20ml) at final concentration of 75ppm. Triplicate samples were prepared for each bacteria isolate and incubated at 280C $\pm 10 \mathrm{C}$ under static condition (Kalyani et al., 2008). $2 \mathrm{ml}$ aliquot of bacteria treated sample was withdrawn at two days intervals for fortnight and centrifuged at $8000 \mathrm{rpm}$ for 15 minutes to separate cell mass (Saratale et al., 2009). Supernatant was measured by spectrophotometer $(\lambda=570 \mathrm{~nm})$ to determine dye degrading ability of each isolate. For control experiment, same procedure was followed without bacteria inoculation. After 14 days of incubation, five bacteria strains which were shown more than $50 \%$ of decolorization ability were selected for further studies.

\section{Determination of bacteria growth rates}

The Total Viable Count (TVC) of the each sample was determined by using standard pour plate method at 2 days interval and the results were recorded as Colony Forming Units (CFU/ml). Normalize the data, an algorithmic transformation of the detected CFU/unit from Log10 (CFU/unit + 0.1f), was performed where, "f" is the reported CFU/unit corresponding to the smallest responsible result. The equation given bellow was used to determine the dye decolorizing rate by bacteria where " $\mathrm{CO}$ " and " $C$ " are the concentration of dye at the beginning and at the end of the time interval " $\mathrm{t}$ " respectively (Manage et al., 2000).

$\mathrm{h}=\ln (\mathrm{C} / \mathrm{C} 0) / \mathrm{t}$

\section{Characterization and identification of isolated bacteria strains}

Selected bacteria isolates were tentatively identified according to their colony characteristics, cellular morphology, staining reactions and biochemical characteristics. Biochemical tests (Starch hydrolysis, Carbohydrate fermentation test, Catalase test, Gelatin liquefaction test, Citrate test, Urease test, Methyl red test, Voges proskauer test, Indole test, Hydrogen sulfide production test) were carried out for each bacteria isolate according to Liyanage \& Manage 2015, under aseptical conditions. Each test was carried out with negative and positive reference samples as well.

\section{Decolorization kinetics with different concentrations of textile dye}

To determine the effect of the bacteria on textile dye, overnight starved bacteria suspensions were equalized to $\mathrm{A} 590=0.35$ and added into sterile water and dye containing universal bottles to obtained final concentration at 50ppm, $75 \mathrm{ppm}$ and 100ppm. Dye degrading ability of each isolated bacteria was tested against for three different dye concentrations in triplicates.

\section{Optimization of environmental factors}

Decolorization under different culture conditions were carried out in triplicates by adjusting temperature at 240C, 280C and 320C and $\mathrm{pH}$ at 5.8, 7.0 and 8.2 respectively. $\mathrm{NaOH}$ and $\mathrm{HCl}$ were used for $\mathrm{pH}$ adjustment where appropriated. $2 \mathrm{ml}$ of subsample from each was collected at two day intervals for a period of 14 days and absorbance were measured at 570nm.

\section{Data analysis}

One-way analysis of variance (ANOVA) with Tukey-Kramer multiple comparisons test and two sample T-test were used for statistical data analysis. Test results were considered as significant when $\mathrm{p}$ was $\leq 0.05$.

\section{RESULTS AND DISCUSSION}

\section{Isolation and identification of dye decolorizing bacteria}

The isolated 35 bacterial strains were exposed to decolorization experiment and decolorization percentages of isolates were varied from $0.01 \pm$ $0.00 \%$ to $58.26 \pm 0.85 \%$. Lower decolorization ability in most bacteria may due to the highly 
stable nature of CI Direct Blue 201 textile dye on natural degradation processes (Ekanayake and Manage, 2016) as the dye has highly complex structure.

Five bacterial strains were able to show more than $50 \%$ of decolorization percentage and they were tentatively identified as Pseudomonas sp., Micrococcus sp., Bacillus sp., Bacillus sp., Pseudomonas sp. respectively and used for further studies.

\section{Bacterial growth rate}

Figure 1 shows the relationship between bacteria $(\mathrm{CFU} / \mathrm{ml})$ and the remaining concentration of dye during 14 days of incubation. Pseudomonas sp. 2 recorded the highest dye decolorization percentage $(58 \%)$ with the highest bacterial density $(2.8 \times 104 \mathrm{CFU} / \mathrm{ml})$ (Figure $1 \mathrm{E})$. The highest decolorization rate was detected when sample was treated with Pseudomonas sp. 1 after two days of incubation (0.094 \pm 0.005 day-1) and thereafter decolorization rate reduced further along with incubation time. Descending order of decolorization rate was recorded by Bacillus sp.1 (0.055 \pm 0.001 day-1), Micrococcus sp. (0.052 \pm 0.011 day- 1$)$, Pseudomonas sp.2 (0.048 \pm 0.001 day- 1$)$ and Bacillus sp.2 (0.017 \pm 0.006 day-1) respectively at second day of incubation (Table 1). After 14 days incubation, Pseudomonas sp.2 showed considerable high decolorization rate.

\section{Optimization of environmental factors}

Aquatic environment is highly susceptible to untreated or partially treated textile dye effluents. Living beings in such aquatic environment must able to tolerate changes in temperature, $\mathrm{pH}$, solar input, organic substrates like various environmental factors (Stevenson, 1977). Therefore effect of key environmental factors on decolorization of CI Direct Blue 201 dye was studied in detail.

Table 1. Bacterial decolorization rate of CI direct blue 201 textile dye at concentration of 75 ppm

\begin{tabular}{|l|l|l|l|l|l|l|}
\hline \multirow{2}{*}{ Day } & \multicolumn{2}{|l|}{ Decolorization rate (ppm day $\mathbf{- 1}^{\mathbf{1}}$ ) } \\
\cline { 2 - 7 } & Control & $\begin{array}{l}\text { Pseudomonas } \\
\text { sp.1 }\end{array}$ & $\begin{array}{l}\text { Micrococcus } \\
\text { sp. }\end{array}$ & Bacillus sp.1 & Bacillus sp.2 & $\begin{array}{l}\text { Pseudomonas } \\
\text { sp.2 }\end{array}$ \\
\hline $0-2$ & $0.000 \pm 0.000$ & $0.094 \pm 0.003$ & $0.052 \pm 0.011$ & $0.055 \pm 0.001$ & $0.017 \pm 0.006$ & $0.048 \pm 0.001$ \\
\hline $2-4$ & $0.002 \pm 0.000$ & $0.039 \pm 0.006$ & $0.029 \pm 0.007$ & $0.035 \pm 0.002$ & $0.016 \pm 0.003$ & $0.056 \pm 0.001$ \\
\hline $4-6$ & $0.050 \pm 0.001$ & $0.059 \pm 0.003$ & $0.029 \pm 0.003$ & $0.017 \pm 0.002$ & $0.016 \pm 0.003$ & $0.079 \pm 0.004$ \\
\hline $6-8$ & $0.010 \pm 0.000$ & $0.049 \pm 0.005$ & $0.034 \pm 0.004$ & $0.052 \pm 0.000$ & $0.107 \pm 0.002$ & $0.043 \pm 0.003$ \\
\hline $8-10$ & $0.000 \pm 0.000$ & $0.054 \pm 0.003$ & $0.052 \pm 0.001$ & $0.045 \pm 0.000$ & $0.077 \pm 0.001$ & $0.042 \pm 0.003$ \\
\hline $10-12$ & $0.070 \pm 0.000$ & $0.066 \pm 0.001$ & $0.061 \pm 0.001$ & $0.053 \pm 0.006$ & $0.133 \pm 0.004$ & $0.100 \pm 0.003$ \\
\hline $12-14$ & $0.000 \pm 0.000$ & $0.018 \pm 0.002$ & $0.120 \pm 0.000$ & $0.011 \pm 0.003$ & $0.055 \pm 0.000$ & $0.069 \pm 0.000$ \\
\hline
\end{tabular}

However the highest significant decolorization was recorded at $50 \mathrm{ppm}$ of initial dye concentration (ANOVA, $\quad \mathrm{p}<0.05$ ). Environmental temperature is one of the major factors that influence the growth and survival of bacteria. Previous studies have revealed that the rate of color removal increased with increasing temperature for some extent (Pearce et al., 2003). Maduri \& Girish (2012) recorded that $25^{\circ} \mathrm{C}$ to $40^{\circ} \mathrm{C}$ is the optimum range of temperature for effective dye removal process by bacterial activity. According to previous studies, $37^{\circ} \mathrm{C}$ was the optimum temperature for
Bacillus sp. (Velmurugan \& Ravikumar, 2014), Micrococcus sp. (Saratale et al., 2009) and Pseudomonas sp. (Kalyani et al., 2008).

Those bacteria have showed their highest decolorizing percentage at $37^{\circ} \mathrm{C}$. In the present study, three temperatures; $24^{\circ} \mathrm{C}, 28^{\circ} \mathrm{C}$ and $32^{\circ} \mathrm{C}$ were employed to optimize most suitable temperature for decolorization process. 280C was considered as room temperature and much higher and lower temperatures were avoided as those are not applicable when selecting bacteria for bioremediation purpose. According to figure 
3 , the decolorization ability was higher in the samples which were incubated at $32{ }^{\circ} \mathrm{C}$ than the other two temperatures. Pseudomonas sp.1
(67.02 $\pm 1.02 \%)$ and Pseudomonas sp.2 (65.77 $\pm 1.08 \%$ ) showed fairly higher decolorization when incubated at $32^{\circ} \mathrm{C}$.
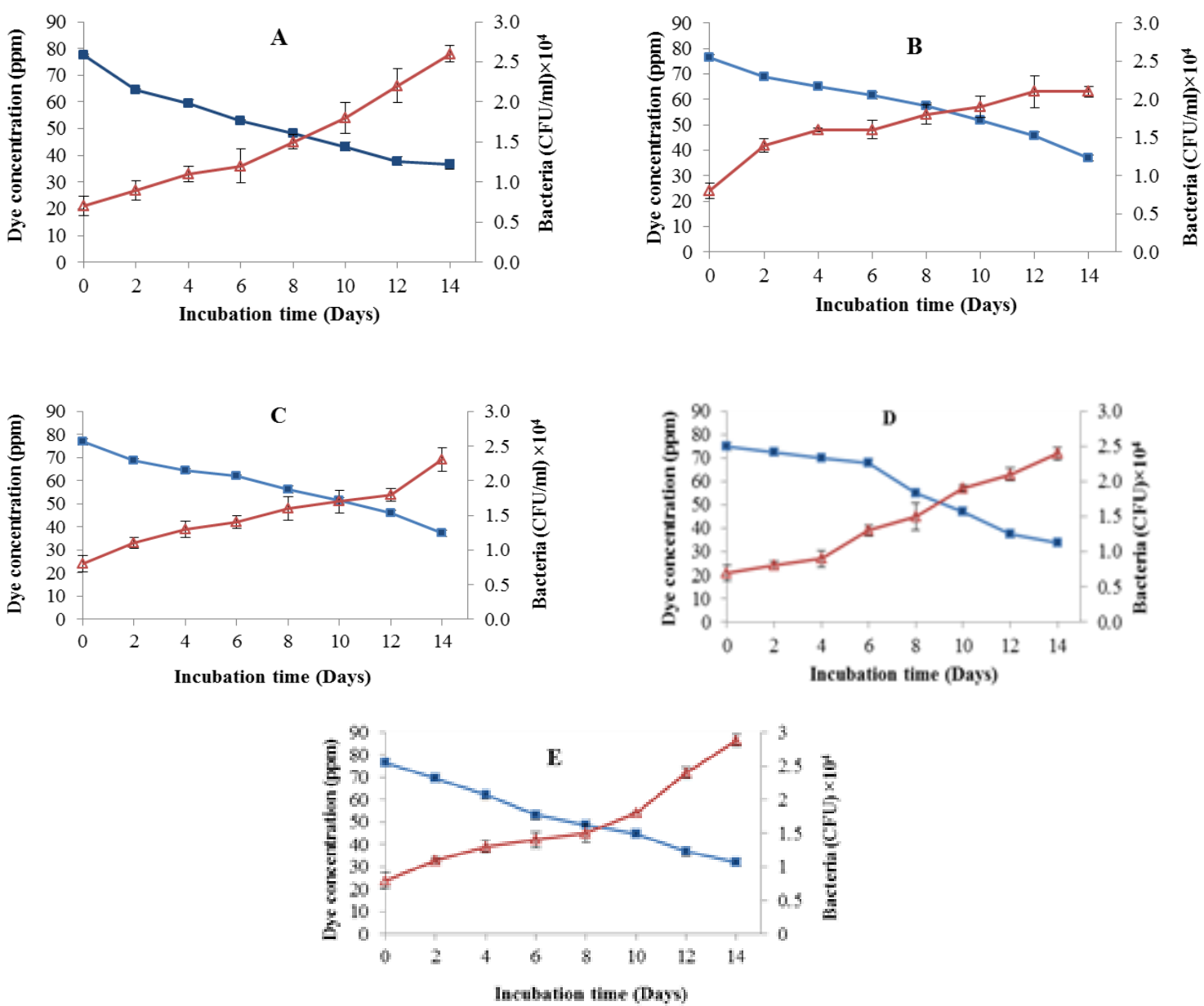

Figure 1. Changes in bacteria cell densities (CFU/ml) along with decolorization of textile dye at final concentration of 75 ppm. A; Pseudomonas sp. 1, B; Micrococcus sp., C; Bacillus sp. 1, D; Bacillus sp. 2, E; Pseudomonas sp. 2. When error bars are not shown, standard deviation was less than the width of symbol. (Closed square; Dye decolorization, Open triangle; Bacteria density as CFU/ml).

Decolorization of textile dyes by bacteria is often occurs via an enzymatic reaction (Asad et al., 2007) and enzymes are highly sensitive to $\mathrm{pH}$ in the medium. Therefore it is necessary to evaluate optimum $\mathrm{pH}$ for each bacterial isolates in order to obtained proper bioremediation conditions. Most azo dyes are completely decolorized by bacteria where $\mathrm{pH}$ is near neutrality (Cui et al., 2014). In the present study, calculate the decolorization percentage of dye after 14 days of incubation by Pseudomonas sp. 1 (55.91 \pm 1.45\%) and Micrococcus sp. (55.54 \pm $1.17 \%$ ) (Figure 4) were showed the highest percentage at $\mathrm{pH}$ 7.0. Further, it was found that, dcolorization ability of bacteria was reduced under acidic pH conditions (5.8). Cui et al., (2014) suggested that azo bonds form protonated azo dyes at extremely acidic $\mathrm{pH}$ 
values. Therefore, bacteria cannot decolorized azo compounds due to this alteration of chemical structure of dye. On the other hand bacterial growth rate is reduced at extreme $\mathrm{pH}$ values and accordingly the enzymes which are responsible for decolorization is denatured (Chen et al., 2003).
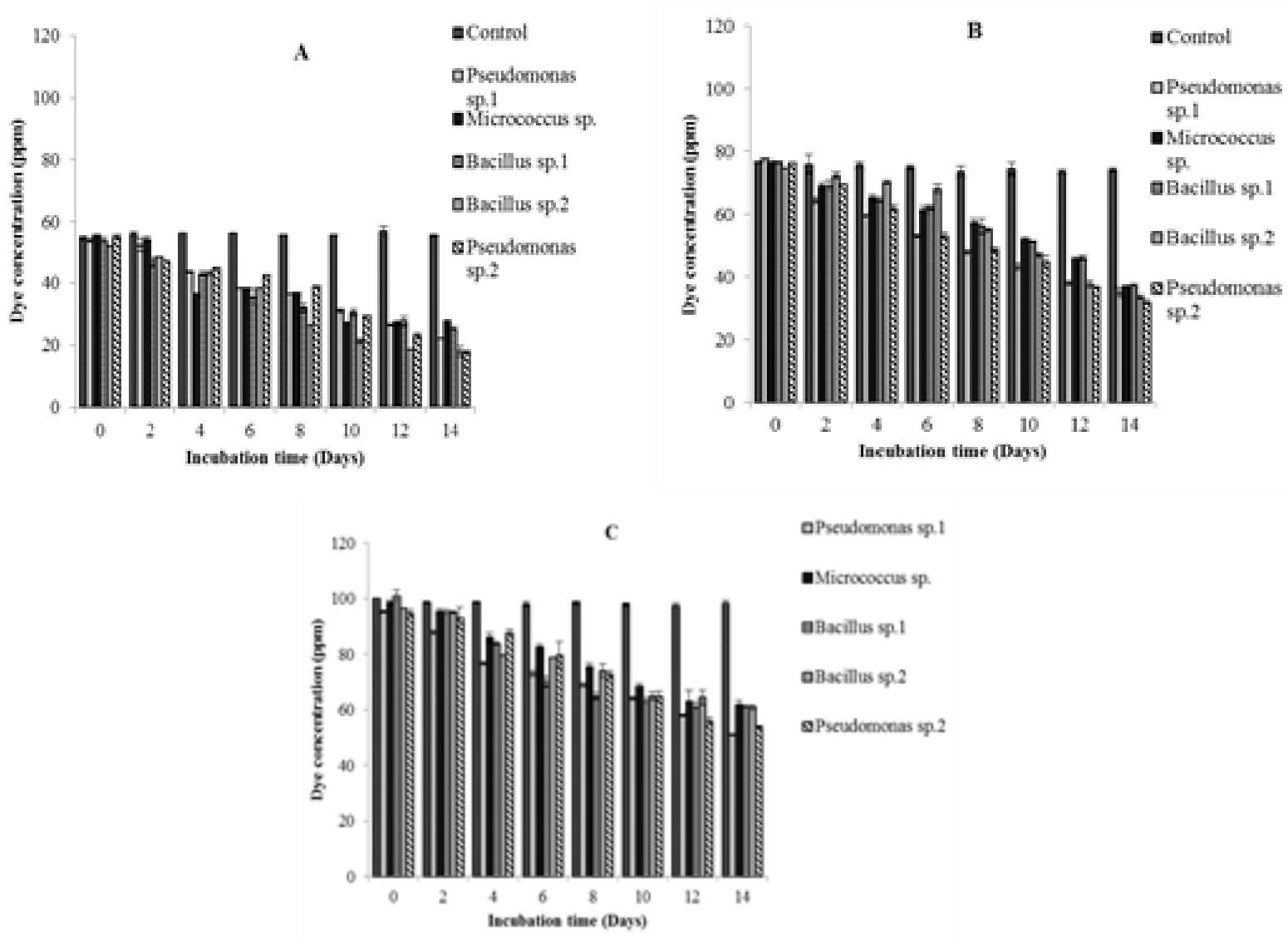

Figure 2. Screening of dye decolorization bacteria against three different dye concentrations. (A); 50 ppm initial concentration, (B); 75 ppm initial concentration, (C) 100 ppm.

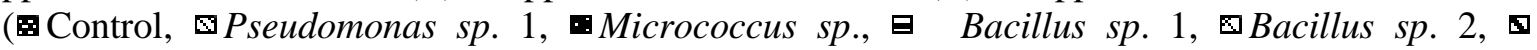
Pseudomonas sp. 2.) When error bars are not shown, standard deviation was less than the width of symbol

Decolorization of textile dyes by bacteria is often occurs via an enzymatic reaction (Asad et al., 2007) and enzymes are highly sensitive to $\mathrm{pH}$ in the medium. Therefore it is necessary to evaluate optimum $\mathrm{pH}$ for each bacterial isolates in order to obtained proper bioremediation conditions. Most azo dyes are completely decolorized by bacteria where $\mathrm{pH}$ is near neutrality (Cui et al., 2014). In the present study, calculate the decolorization percentage of dye after 14 days of incubation by Pseudomonas sp. 1
(55.91 \pm 1.45\%) and Micrococcus sp. (55.54 \pm $1.17 \%$ ) (Figure 4) were showed the highest percentage at $\mathrm{pH}$ 7.0. Further, it was found that, dcolorization ability of bacteria was reduced under acidic $\mathrm{pH}$ conditions (5.8). Cui et al., (2014) suggested that azo bonds form protonated azo dyes at extremely acidic $\mathrm{pH}$ values. Therefore, bacteria cannot decolorized azo compounds due to this alteration of chemical structure of dye. On the other hand bacterial growth rate is reduced at extreme $\mathrm{pH}$ values and 
accordingly the enzymes which are responsible for decolorization is denatured (Chen et al., 2003).

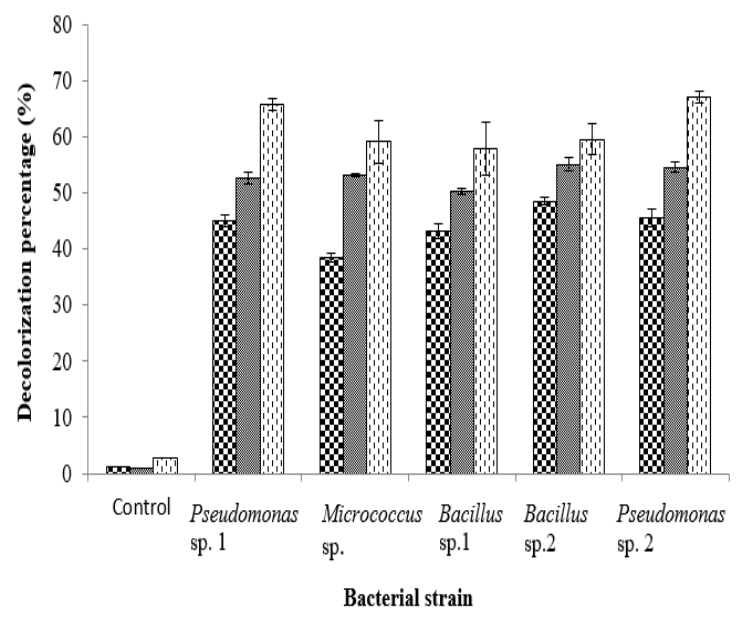

Figure 3. Dye decolorization percentage by isolated bacteria at $75 \mathrm{ppm}$ of dye concentration with different temperature conditions. When error bars are not shown, standard deviation was less than the width of symbol. (Checked; $24^{\circ} \mathrm{C}$, dotted; $28^{0} \mathrm{C}$, hachure; $32^{\circ} \mathrm{C}$ )

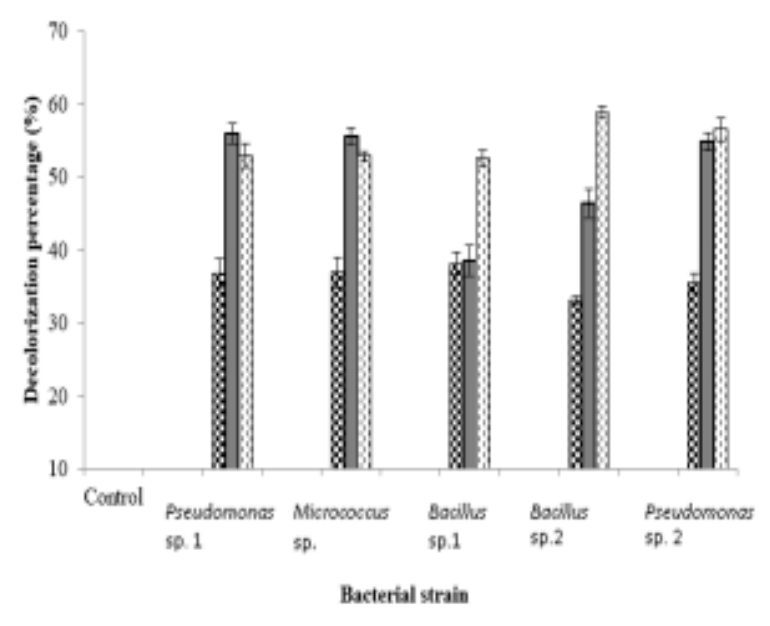

Figure 4. Dye decolorization percentage by isolated bacteria in different $\mathrm{pH}$. When error bars are not shown, standard deviation was less than the width of symbol. (Checked; $\mathrm{pH} 5.8$, dotted; $\mathrm{pH}$ 7.0, hachure; $\mathrm{pH}$ 8.2)

\section{CONCLUSION}

In the present study, 35 bacterial colonies were isolated from textile dye effluent water samples and five of them were screened as potential candidates for decolorization of CI direct blue 201 textile dye. The isolated bacteria strains were tentatively identified as Pseudomonas sp.1, Micrococcus sp., Bacillus sp.1, Bacillus sp.2, and Pseudomonas sp.2. Among them, Pseudomonas sp.2. showed the highest decolorization percentage (58\%). All five bacteria species showed highest decolorization percentage when the concentration of dye was at $50 \mathrm{ppm}$ and temperature was at 320C. Decolorization ability of bacteria was reduced at acidic $\mathrm{pH}$ conditions was found. Photolysis study on CI direct blue 201 confirmed that the structure of dye is recalcitrant to the natural sun light as it consists with complex structure; two azo bonds, three sulfo groups and five aromatic rings. Hence, present study reveals that bioremediation through bacteria are perfect answer for decolorization of dye containing waste water in natural environment. But further studies are needed to elucidate the dye decolorization mechanism and the toxicity of daughter compounds to use those isolated bacteria in industrial waste water treatment aspects.

\section{REFERENCES}

ABRAHAM TE, SENAN RC, SHAFFIQU TS, ROY JJ, POULOSE TP \& THOMAS P. Bioremediation of textile azo dyes by an aerobic bacterial consortium using a rotating biological contactor. Biotechnology progress. 2003; 19(4): 1372-1376.

ANDREONI $\mathrm{V}$ \& GIANFREDA L. Bioremediation and monitoring of aromatic polluted habitats. Applied microbiology biotechnology. 2007; 76: 287-308. 
APHA Standard methods for examination of water and waste water. 19th Edition. Washington, DC: American Public Health Association. 1995.

ASAD S, AMOOZEGAR MA, POURBABAEE A, SARBOLOUKI MN \& DASTGHEIB SMM. Decolorization of textile azo dyes by newly isolated halophilic and halotolerant bacteria. Bioresource technology. 2007; 98(11): 20822088.

AZHAR SS, LIEW AG, SUHARDY D, HAFIZ, KF \& HATIM MDI. Dye removal from aqueous solution by using adsorption on treated sugarcane bagasse. American journal of applied sciences. 2005; 2(11): 1499-1503.

BANAT IM, NIGAM P, SINGH D \& MARCHANT R. Microbial decolorization of textile-dyecontaining effluents. Bioresource technology. 1996; 58(3): 217-227.

CHANG WS, HONG SW \& PARK J. Effect of zeolite media for the treatment of textile wastewater in a biological aerated filter. Process Biochemistry. 2002; 37(7); 693-698.

CHEN KC, WU JY, LIOU DJ \& HWANG SJ. Decolorization of the textile dyes by newly isolated bacterial strains. Journal of Biotechnology. 2003; 101: 57-68.

CHEQUER FMD, DORTA DJ \& OLIVEIRA DP. Azo dyes and their metabolites: Does the discharge of the azo dye into water bodies represent human and ecological risks. 2011; 2749. INTECH open access publisher.

CLAUDIO L. Waste couture: environmental impact of the clothing industry. Environment health perspectives. 2007; 115: 449-454.

CRINI G. Non-conventional low-cost adsorbents for dye removal. Bioresource technology. 2006; 97(9): 1061-1085.
CUI D, LI G, ZHAO $\mathrm{M}$ \& HAN S. Decolourization of azo dyes by a newly isolated Klebsiella sp. strain Y3, and effects of various factors on biodegradation. Biotechnology \& biotechnological equipment. 2014; 28(3): 478486.

EKANAYAKE EMMS \& MANAGE PM. Decoloriztion of textile dye (CI Direct Blue 201) by selected aquatic plants. The 2 nd Environment and Natural Resources International Conference Proceeding. 2016; 25.

ENGADE K \& GUPTA S. Adsorption of synthetic dye and dyes from a textile effluent by dead microbial mass. Journal of industrial pollution control. 2007; 23(1): 145-150.

GUPTA N, KUSHWAHA AK \& CHATTOPADHYAYA MC. Application of potato (Solanum tuberosum) plant wastes for the removal of methylene blue and malachite green dye from aqueous solution. Arabian journal of chemistry. 2011; 4: 353-358.

HARVEY H. Spectroscopic Methods. 2000. http://www.saylor.org/site/wpcontent/uploads/2012/07/Chapter1011.pdf. Accessed 03 March, 2015.

JADHAV SB, YEDURKAR SM, PHUGARE SS \& JADHAV JP. Biodegradation studies on acid violet 19, a triphenylmethane dye, by Pseudomonas aeruginosa. Clean soil air water. 2012; 40: 551-558.

KALYANI DC, PATIL PS, JADHAV JP \& GOVINDWAR SP. Biodegradation of reactive textile dye red BLI by an isolated bacterium Pseudomonas sp. SUK1. Bioresource technology. 2008; 99(11): 4635-4641.

LIYANAGE GY \& MANAGE PM. Optimisation of Environmental Factors on Oil Degrading Bacteria Isolated from Coastal Water and Sediments in Sri Lanka. Journal of Tropical Forestry and Environment. 2015; 13-25. 
MADHURI S \& GIRISH P. Biomethanation of dye industry wastewater. Univesal journal of environmental research and technology. 2012; 2(3): 179-187.

MAHAGAMAGE MGYL, CHINTHAKA SDM \& MANAGE PM. Multivariate analysis of physico-chemical and microbial parameters of surface water in Kelani river basin. International Journal in Multidisciplinary Studies (IJMS). 2014; 1: 55-61.

MANAGE P, EDWARDS C \& LAWTON L. Bacterial degradation of microcystin. Interdisciplinary Studies on Environmental Chemistry-Biological Responses to Contaminants. TERRAPUB: Tokyo. 2010; 97104.

MANAGE PM, EDWARDS C, SINGH BK \& LAWTON LA. Isolation and identification of novel microcystin-degrading bacteria. Applied and environmental microbiology. 2009b; 75(21): 6924-6928.

MANAGE PM, EDWARDS C \& LAWTON L. Biodegradation of microcystin-LR by Natural bacterial populations. Interdisciplinary Studies on Environmental Chemistry - Environmental Research in Asia. 2009a; 277-285.

MANAGE PM, KAWABATA ZI \& NAKANO SI. Algicidal effect of the bacterium Alcaligenesdenitrificans on Microcystis spp. Aquatic microbial ecology. 2000; 22(2): 111117.

O'NEILL C, HAWKES FR, HAWKES DL, LOURENÇO ND, PINHEIRO HM \& DELEE W. Colour in textile effluents-sources, measurement, discharge consents and simulation. Journal of chemical technology and biotechnology. 1999; 74(11): 1009-1018.

PEARCE CI, LLOYD JR \& GUTHRIE JT. The removal of colour from textile wastewater using whole bacterial cells. Dyes and pigments. 2003; 58(3): 179-196.
PEREIRA L \& ALVES M. Dyes- environmental impact and remediation. Environmental protection strategies for sustainable development. 2012; 111-162.

PUVANESWARI N, MUTHUKRISHNAN J \& GUNASEKARAN P. Toxicity assessment and microbial degradation of azo dyes. Indian journal of experimental biology. 2006; 44(8): 618-626.

ROBINSON T, MCMULLAN G, MARCHANT R \& NIGAM P. Remediation of dyes in textile effluent: a critical review on current treatment technologies with a proposed alternative. Bioresource technology. 2001; 77(3): 247-255.

SARATALE RG, SARATALE GD, KALYANI DC, CHANG JS \& GOVINDWAR SP. Enhanced decolorization and biodegradation of textile azo dye scarlet $\mathrm{R}$ by using developed microbial consortium-GR. Bioresource technology. 2009; 100(9): 2493-2500.

STEVENSON LH. A case for bacterial dormancy in aquatic systems. Microbial ecology. 1977; 4(2): 127-133.

VELMURUGAN S \& RAVIKUMAR R. Biodegradation and decolorization of reactive dye red ME4BL by Bacillus subtilis. International journal of environmental bioremediation \& biodegradation. 2014; 2(6), 250-255.

ZHOU X \& XIANG X. Effect of different plants on azo-dye wastewater bio-decolorization. Procedia environmental sciences. 2013; 18: 540546. 